\title{
Annulation Reactions Catalyzed by Amberlite-Bound Hexafluorophosphate
}

\section{Gategory}

Polymer-Supported Synthesis

\section{Key words}

catalysis

Amberlite

diamines

benzimidazoles

quinoxalines
Selected examples:<smiles>c1ccc(Cn2c(-c3ccccc3)nc3ccccc32)cc1</smiles>

$96 \%$ yield (r.t., $1 \mathrm{~h}$ )<smiles>COc1ccc(Cn2c(-c3ccc(OC)cc3)nc3ccccc32)cc1</smiles>

$88 \%$ yield (r.t., $2 \mathrm{~h}$ )

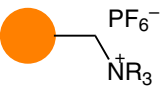

(eq. 1)

Amberlite- $-\mathrm{PF}_{6}$ (eq. 2)

$3 \mathrm{R}^{2}$

25 examples, $72-96 \%$ yield<smiles>O=[N+]([O-])c1ccc(Cn2c(-c3ccc([N+](=O)[O-])cc3)nc3ccccc32)cc1</smiles>

$79 \%$ yield (r.t., $8 \mathrm{~h}$ )<smiles>c1ccc(Cn2c(-c3ccncc3)nc3ccccc32)cc1</smiles><smiles>c1ccc2c(c1)nc(C1CCCCC1)n2CC1CCCCC1</smiles><smiles>C(=C/c1ccccc1)\Cn1c(/C=C/c2ccccc2)nc2ccccc21</smiles><smiles>Cn1cnc2ccccc21</smiles>
$68 \%$ yield (r.t., $8 \mathrm{~h}$ )

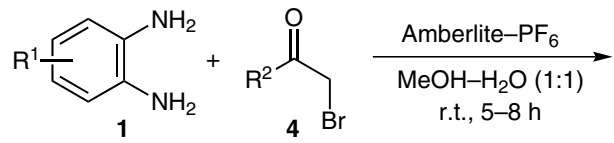

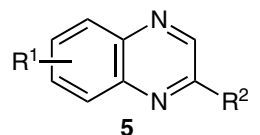

(eq. 3)
Significance: Amberlite resin-bound hexafluorophosphate (Amberlite- $\mathrm{PF}_{6}$ ) was prepared by treatment of Amberlite 900 with aqueous $\mathrm{NaPF}_{6}$ (eq. 1). In the presence of Amberlite- $\mathrm{PF}_{6}$, the annulation of phenylenediamines $\mathbf{1}$ with aldehydes $\mathbf{2}$ took place to give the corresponding benzimidazoles 3 (25 examples, 72-96\% yield).

SYNFACTS Contributors: Yasuhiro Uozumi, Makoto Nagaosa Synfacts 2013, 9(1), 0113 Published online: 17.12.2012 Dol: 10.1055/s-0032-1317917; Reg-No.: Y14612SF
Comment: The binding of hexafluorophosphate on Amberlite resin was confirmed by IR spectra (557 and $832 \mathrm{~cm}^{-1}$ ), though other characterizations were not given. Phenylenediamines 1 also reacted with $\alpha$-bromoketones 4 in the presence of Amberlite- $\mathrm{PF}_{6}$ to give the corresponding quinoxalines $\mathbf{5}$ via an aromatization step. 